\title{
RUBIÃO, INIMIGO DE SI: A REPRESENTAÇÃO DA INTERIORIDADE EM QUINCAS BORBA, DE MACHADO DE ASSIS ${ }^{1}$
}

\section{TIAGO SEMINATTI}

Universidade de São Paulo São Paulo, São Paulo, Brasil

Resumo: Este artigo propõe um estudo crítico sobre Quincas Borba, de Machado de Assis, considerando a articulação discursiva entre o protagonista Rubião e o narrador. Para isso, cotejamos as duas versões do romance: em folhetim, publicada no periódico A Estação (1896-1891), e em livro, publicada em 1891. Diferenças entre elas sinalizam a importância que o discurso indireto livre tem no processo de escrita do texto, cujo modo de narrar sugere a moderna coisificação dos homens por outros homens.

Palavras-chave: Machado de Assis; Quincas Borba; discurso indireto livre.

\section{RUBIÃO, ENEMY OF HIMSELF: \\ A STUDY ON INNER-SELF REPRESENTATION IN MACHADO DE ASSIS'S QUINCAS BORBA ${ }^{2}$}

\begin{abstract}
This article purposes a critical study about Machado de Assis's Quincas Borba by considering the discursive interconnection between the protagonist, Rubião, and the narrator. Therefore, we compare two versions of the novel: the serial version, published in A Estação (1886-1891), and the book version, published in 1891. Differences between the two suggest that free indirect speech is essential to the author's writing process, whose narrative technique suggests the modern objectifying of men by men.
\end{abstract}

Keywords: Machado de Assis; Quincas Borba; free indirect speech.

\footnotetext{
${ }^{1}$ Neste artigo, recupero material e dialogo com passagens de minha dissertação de mestrado, "A interioridade em abismo: estudo sobre o discurso indireto livre e a crise da forma em Quincas Borba" (2016).

${ }^{2}$ In this article I make use of material from, and dialogue with my master's thesis "A interioridade em abismo: estudo sobre o discurso indireto livre e a crise da forma em Quincas Borba" (2016).
} 
- Ao vencedor as batatas! Não a compreenderia antes do testamento; ao contrário, vimos que a achou obscura e sem explicação. Tão certo é que a paisagem depende do ponto de vista, e que o melhor modo de apreciar o chicote é ter-lhe o cabo na mão.

Machado de Assis, Quincas Borba

Q uincas Borba (1891), de Machado de Assis, apresenta uma interessante articulação do discurso narrativo com o ponto de vista do protagonista Rubião. Nas linhas do romance, acompanhamos seus passos no Rio de Janeiro, que ocorrem após ter deixado a provinciana Barbacena com uma fortuna herdada do amigo Quincas Borba. Em solo fluminense, a paixão por Sofia é mola propulsora para seus enganos e devaneios. Relacionada com a crise material, a crise psíquica de Rubião proporciona sua marginalização social. No final, depois de ter sido recolhido a uma casa de saúde, o personagem retorna à terra natal para morrer sem terminar de pronunciar a fórmula humanitista que aprendera com o filósofo Quincas - "Ao vencedor, as batatas".

Embora tal resumo sinalize o aspecto sombrio e o final melancólico da narrativa, ele não basta para uma compreensão de Quincas Borba, pois a ação, nesse romance, alcança significação mais ampla devido ao modo como a narração é configurada, importando a sua construção discursiva. É por meio de sutis combinações de palavras que a narrativa potencializa o sentido dos eventos: a aquisição da fortuna e sua espoliação, a crise psíquica e a morte de Rubião impactam o leitor porque o modo como tais acontecimentos são narrados é assombroso, elaborado num jogo de aproximação e distanciamento que o narrador executa em relação aos personagens, principalmente o protagonista.

Logo no primeiro capítulo, temos o ponto de vista de Rubião servindo aos intentos do narrador a partir de vários níveis de aproximação:

Rubião fitava a enseada - eram oito horas da manhã. Quem o visse, com os polegares metidos no cordão do chambre, à janela de uma grande casa de Botafogo, cuidaria que ele admirava aquele pedaço de água quieta; mas, em verdade, vos digo que pensava em outra cousa. Cotejava o passado com o presente. Que era, há um ano? Professor. Que é agora? Capitalista. Olha para si, para as chinelas (umas chinelas de Túnis, que 
lhe deu recente amigo, Cristiano Palha), para a casa, para o jardim, para a enseada, para os morros e para o céu; e tudo, desde as chinelas até o céu, tudo entra na mesma sensação de propriedade.

- Vejam como Deus escreve direito por linhas tortas, pensa ele. Se mana Piedade tem casado com Quincas Borba, apenas me daria uma esperança colateral. Não casou; ambos morreram, e aqui está tudo comigo; de modo que o que parecia uma desgraça... (ASSIS, 1977, p. $107)^{3}$

Após descrever Rubião "com os polegares metidos no cordão do chambre, à janela de uma grande casa de Botafogo" (ASSIS, 1977, p. 107), o narrador expõe a atividade mental do ex-professor, que compara seu passado humilde com o presente abastado: "Que era, há um ano? Professor. Que é agora? Capitalista" (ASSIS, 1977, p. 107). Apesar de integrar a enunciação do narrador, o trecho remete ao que seria o discurso interior do personagem, sugerindo que as perguntas e as respostas provêm deste último. $\mathrm{Na}$ sequência, altera-se a forma de transmissão do discurso e a interioridade de Rubião adentra a narração pela via direta, revelando um pensamento que apresenta informações sobre meandros que envolvem a aquisição da herança: "- Vejam como Deus escreve direito por linhas tortas, pensa ele. Se mana Piedade tem casado com Quincas Borba, apenas me daria uma esperança colateral. Não casou; ambos morreram, e aqui está tudo comigo; de modo que o que parecia uma desgraça..." (ASSIS, 1977, p. 107). Em capítulo posterior, sabemos que Rubião, no passado, fizera o possível para que Piedade e Quincas Borba casassem - acontecimento que poderia desencadear um filho. Resistente ao matrimônio, Piedade morre e inviabiliza o projeto do irmão, que não alcança "uma esperança colateral", ou seja, um parentesco de segundo grau com o amigo filósofo. Assim, a partir da condição de herdeiro universal, Rubião reavalia como os fatos passados proporcionaram sua alegria presente, atribuindo o arranjo deles à obra divina. Nesse primeiro capítulo, portanto, temos um narrador que busca construir a cena e apresentar informações valendo-se de fragmentos

\footnotetext{
${ }^{3}$ Fizemos uma alteração no trecho citado: em "Que é agora?", na edição crítica da Comissão Machado de Assis há um ponto de exclamação, em vez de um ponto de interrogação. Embora tenhamos adotado o volume estabelecido pela referida Comissão como texto base, constatamos que no volume de 1891, publicado pela Garnier e disponível no acervo digital da Biblioteca Brasiliana Guita e José Mindlin (https://www.bbm.usp.br/), consta o ponto de interrogação, assim como na versão em folhetim estabelecida pela mesma Comissão e nos textos (versão livro e versão folhetim) presentes em machadodeassis.net. Assim, considerando tais edições e o sentido do texto, optamos pelo ponto de interrogação.
} 
psíquicos do ser fictício, que filtra a compreensão do mundo e, por sua vez, delimita o ponto de vista narrativo.

No capítulo seguinte, mantém-se a proeminência da representação do discurso interior de Rubião na narração a partir da elaboração de uma dicotomia para a esfera psíquica dele, dividida entre "o espírito e o coração" (ASSIS, 1977, p. 107). A divisão evidencia a discrepância interna que ocorre no personagem, que censura a si mesmo por comemorar a aquisição da herança resultante de insucesso matrimonial e morte do amigo, ao passo que avalia euforicamente a eficiência da providência divina, uma vez que obstáculos para o recebimento do espólio não o prejudicaram. Embora sejamos impelidos a atribuir cinismo a Rubião por causa do acento irônico que se subentende no trecho - "uma vez que a mana Piedade tinha de morrer, foi bom que não casasse; podia vir um filho ou uma filha..." (ASSIS, 1977, p. 107) -, o julgamento inexiste por parte do narrador, cujo discurso expõe, no final do capítulo, o pensamento do personagem mais uma vez na forma direta, estilizando seu fluxo interior: "- Bonita canoa! - Antes assim! Como obedece bem aos remos do homem! - O certo é que eles estão no céu!" (ASSIS, 1977, p. 107). Mesmo procurando cercear a alegria motivada por algo que é consequência de acontecimentos tristes e fúnebres, Rubião tem seu contentamento desnudado por meio de migalhas psíquicas que surgem em formulações socialmente inconfessas acerca do recebimento da herança. A narração busca acentuar a disparidade entre aquilo que o personagem vê e aquilo que habita sua interioridade, disparidade essa evidenciada pela observação da canoa, com seu condutor, e da certeza - bastante interessada de que os finados Quincas e a irmã Piedade estão no céu. Nesse sentido, por meio de um narrador que penetra a alma do personagem, tal contraste entre as esferas exterior e interior escancara a inconstância psíquica de Rubião e revela para o leitor aquilo que é socialmente inconfessável.

Portanto, da exposição da interioridade de Rubião na narração surge um procedimento interessado em absorver vocábulos, tons ou mencionar diretamente pensamentos provenientes da representação do discurso interior do personagem, efetuando, conforme vimos, um desnudamento de cálculos inconfessos e motivações silenciadas na esfera do convívio social. Fundamental em todo o romance, esse traço narrativo se mantém e intensifica no terceiro capítulo, quando a cena matinal prossegue. Nele, depois de certa interação com o criado, Rubião, novamente sozinho, mira gravuras inglesas, visão que o faz relembrar Sofia, que sugeriu a compra dos objetos. A observação que o personagem faz sobre o mundo exterior, assim como nos dois capítulos anteriores, serve como ponte para sua interioridade: 
Rubião suspirou, cruzou as pernas, e bateu com as borlas do chambre sobre os joelhos. Sentia que não era inteiramente feliz; mas sentia também que não estava longe a felicidade completa. Recompunha de cabeça uns modos, uns olhos, uns requebros sem explicação, a não ser esta, que ela o amava, e que o amava muito. Não era velho; ia fazer quarenta e um anos; e, rigorosamente, parecia menos. Esta observação foi acompanhada de um gesto; passou a mão pelo queixo, barbeado todos os dias, cousa que não fazia dantes, por economia e desnecessidade. Um simples professor! Usava suíças (mais tarde deixou crescer a barba toda), - tão macias, que dava gosto passar os dedos por elas... (ASSIS, 1977, p. 108 , grifos meus)

O parágrafo inicia apresentando uma visão dos gestos exteriores de Rubião, algo que se modifica com o emprego do verbo "sentir" no imperfeito e o adjetivo "feliz", que direcionam o entendimento do leitor para a esfera interior do personagem. Este revê, na memória, uma Sofia com "uns modos", "uns olhos" e "uns requebros" que só seriam explicáveis pelo fato de que a esposa do Palha "o amava muito", algo que mais adiante se apresentará como um equívoco: assim, embora o narrador seja o responsável pela enunciação, o discurso está contaminado pelas palavras e por assertivas que revelam o modo desacertado como Rubião concebe o mundo. Na sequência, os trechos "Não era velho; ia fazer quarenta e um anos; e, rigorosamente, parecia menos", "Um simples professor!" e "que dava gosto passar os dedos por elas..." intensificam a convivência do discurso do personagem com o discurso do narrador, pois temos uma combinação "das entoações da personagem (empatia) e das entoações do autor (distanciamento) dentro dos limites de uma mesma e única construção linguística", conforme Bakhtin (2006, p. 195) explica acerca do discurso indireto livre. Nesse sentido, nas passagens grifadas, o interesse do narrador pela psique de Rubião atinge a forma narrativa de modo a manter em tensão, num mesmo enunciado, os discursos de ambos.

Vale lembrar que, de acordo com Bakhtin (2015, p. 27), o romance como gênero apresenta uma pluralidade de estilos, uma heterogeneidade discursiva e vocal que o romancista, por sua vez, orquestra estilisticamente: "Nele, o pesquisador esbarra em várias unidades estilísticas heterogêneas, às vezes jacentes em diferentes planos da linguagem e subordinadas às leis da estilística." Situado dentre os tipos básicos de tais unidades, os "discursos dos heróis" (BAKHTIN, 2015, p. 100) nem sempre surgem na forma direta e muitas vezes influenciam o discurso do narrador, introduzindo nele a 
heterodiscursividade. Dessa maneira, o romance apresenta "zonas" em que a "voz do herói" "se junta à voz do autor":

[...] Essas zonas são formadas por semidiscursos dos heróis, pelas diferentes formas de transmissão dissimulada da palavra do outro, por disseminadas palavras e palavrinhas do discurso do outro, pelas invasões do discurso do autor por elementos expressivos (reticências, perguntas, exclamações do outro) alheios. (BAKHTIN, 2015, p. 101-102)

Portanto, a narração não raro é contaminada pelos "tons e ponto de vista" do personagem (BAKHTIN, 2015, p. 104), apresentando construções híbridas nas quais as diferenças de visão de mundo entre "autor" - ou narrador - e "personagem" produzem acentos irônicos (BAKHTIN, 2015, p. 105). No caso de Quincas Borba, o apagamento dos limites entre o discurso do narrador e de Rubião é decisivo para a representação de uma interioridade em crise e dialoga com os preceitos teóricos de Bakhtin, visto que permite combinar a arquitetada instabilidade interior do personagem com a narração dos acontecimentos. Conforme o estudioso observa, a articulação discursiva entre narrador e personagem "é um dos mais importantes privilégios da prosa romanesca, que não é acessível aos gêneros dramáticos nem aos puramente poéticos" (BAKHTIN, 2015, p. 107-8).

Desse modo, para além da concepção estanque acerca dos três modelos sintáticos de transmissão do discurso de outrem - discurso direto, indireto e indireto livre -, a proposição teórica de Bakhtin (2015, p. 107) chama a atenção para o "jogo diversificado de discursos dos heróis", no qual uns exercem influência sobre outros: essa ressonância, por sua vez, decorre das diferentes combinações dos modelos de transmissão e "por diferentes meios de sua molduragem replicadora e de sua estratificação alternada pelo contexto" (BAKHTIN, 2015, p. 107) do narrador.

Em Quincas Borba, a incorporação do ponto de vista de Rubião à narração permite que a representação de sua interioridade crie zonas de interferência e que, com frequência, coincida, num mesmo enunciado, com o ponto de vista do narrador. Este se aproxima do personagem, revelando a atividade psíquica do ser fictício para, em seguida, recuperar o distanciamento - discursivo e de visão de mundo - em relação a ele. Assim, temos um interessante contraste entre o plano da ação e aquilo que permanece silenciado no convívio social, cacos da interioridade do ser fictício a que só narrador e leitores têm acesso. Embora tal modo de narrar não seja incomum em outros romances de Machado e de outros autores dos oitocentos, Quincas Borba chama a atenção pelo fato de ser protagonizado 
por um personagem em profunda crise psíquica. No desenvolvimento do enredo, a instabilidade interior de Rubião se intensifica a tal ponto que reverbera na própria instabilidade da narração.

Quincas Borba foi escrito de modo descontínuo e possui duas versões que apresentam diferenças significativas entre elas: uma em folhetim, publicada na revista quinzenal $A$ Estação entre 15 de junho de 1886 e 15 de setembro de 1891, e outra em livro, que saiu em novembro de 1891 pela Garnier. As mudanças realizadas por Machado de Assis, quando da reescrita do romance, interessam-nos porque sugerem o enfoque de seu trabalho na captação da interioridade de Rubião. Nesse sentido, retomaremos passagens de estudos críticos sobre as duas versões e, em seguida, estudaremos casos envolvendo mudanças que expandiram a heterogeneidade discursiva de Quincas Borba.

Em ensaio publicado na década de 1960, Augusto Meyer (1964) escreve sobre variantes existentes entre as duas versões do romance, motivado pela então recente republicação da versão em folhetim, que aconteceu em 1959 a partir de um trabalho da Comissão Machado de Assis, da qual o crítico fez parte. Meyer (1964, p. 174) observa que o romance, no periódico, "começava então pelo começo, isto é, pela doença e morte de Quincas Borba, em Barbacena"; ou seja, apresentava os acontecimentos respeitando a linearidade cronológica. Nesses capítulos, há um afluxo de diálogos, que indicava "uma tendência para uma ação dramática mais simples e direta" (MEYER, 1964, p. 174). Por outro lado, na versão em livro, o início está centrado em Rubião e em suas divagações interiores. Assim, na reescrita, a alteração na abertura do romance passou a colocar o foco na interioridade do personagem, em detrimento da forma dialogada. Essa mudança sugere aquilo que Meyer (1964, p. 188) detecta como característica fundamental de Quincas Borba: um "agudo faro" na captação da instabilidade dos "estados de consciência" dos personagens.

Posteriormente, em 1976, John Kinnear tratou do processo de composição de Quincas Borba em "Machado de Assis: to Believe or not to Believe", defendendo que as mudanças de uma versão para outra são representativas do rumo que Machado deu à sua ficção, que apresentaria narradores confiáveis nos primeiros romances e não confiáveis a partir de Memórias póstumas de Brás Cubas (1881). Para Kinnear (1976, p. 60), enquanto a versão em folhetim de Quincas Borba mantém-se mais afinada ao narrador convencional e confiável dos primeiros romances, a versão em livro apresenta um segundo plano de significado, expondo agressivamente artifícios do Realismo literário, em sua busca de efeitos de realidade. Além 
disso, o crítico detecta uma inquietude de Machado durante a escrita dos folhetins, principalmente quando da suspensão da publicação nos períodos de maio a outubro de 1888 e de julho a novembro de 1889 , intervalos que proporcionaram que a narrativa ressurgisse mais enxuta e com alteração na numeração de capítulos. A compreensão desses intervalos enquanto sintomas de uma crise de composição foi amplificada por John Gledson uma década mais tarde.

Em 1986, Gledson (2003, p. 125) dedicou um capítulo de Machado de Assis: ficção e história para tratar de Quincas Borba e o processo de composição do romance a partir da ideia de que "existe um acordo entre a configuração da História e a forma da literatura." Assim, dentre os vários elementos envolvidos na reformulação do romance, o crítico ressalta a importância que o protagonista assume, pois propõe que Machado transformou a narrativa de modo que a crise psíquica de Rubião fosse além da psicologia individual - resultado da tensão entre o homem provinciano e aspectos da vida na Corte - e incorporasse conflitos da sociedade brasileira, principalmente a crise política do final da década de 1860. Nesse sentido, a identificação de Rubião com Napoleão III corresponderia a um paralelo entre a crise política brasileira e a queda do Segundo Império francês, que ocorreu em 1870. Ao considerar que tal identificação entre a personagem histórica francesa e a ficcional brasileira foi engendrada por Machado depois de um dos maiores intervalos sem publicação no periódico, Gledson toma isso como um dos exemplos de soluções encontradas pelo escritor para dar ao romance uma dimensão alegórica. As diferenças entre as versões sinalizam, segundo ele, o desejo de fazer de Rubião um personagem que vai além de uma individualidade, configurando-o como "uma entidade muito maior e mais vaga, 'a nação brasileira"' (GLEDSON, 2003, p. 127).

Em 2010, Ana Cláudia Suriani da Silva publicou o estudo Machado de Assis's "Philosopher or Dog?": from Serial to Book Form. Nele, a pesquisadora explora a relação que Machado de Assis estabeleceu com os periódicos quando das publicações de seus romances, mostrando que as condições materiais disponíveis para o escritor desempenham um papel importante no processo de composição das obras. Acerca das duas versões de Quincas Borba, Suriani (2010, p. 69-70) defende que são obras autônomas e que proporcionam experiências de leitura distintas, já que, além das diferenças textuais, na versão em folhetim há o contato fragmentado com o texto e o diálogo com conteúdos da revista, como anúncios, artigos e gravuras. Sobre a crise psíquica de Rubião, observa "uma mudança sutil no posicionamento do narrador" em relação a esse personagem na reescrita dos capítulos 58 a 62, 
inexistentes na versão da edição crítica da Comissão Machado de Assis e encontrados por ela durante sua pesquisa (SILVA, 2015, p. 223). Sobre a versão em livro, a pesquisadora observa:

O processo de eliminação e incorporação de diálogos à voz narrativa dá a esse trecho um novo ritmo. Machado cria uma nova cadência de vozes, tornando mais tênue a passagem do discurso direto para o discurso indireto livre. Esse movimento nos permite penetrar nos pensamentos de Rubião, sem a quebra do diálogo, como acontecia na versão seriada. (SILVA, 2015, p. 225)

A seguir, procuraremos mostrar que a observação de Suriani acerca da reescrita desses capítulos não é um caso isolado no processo de composição de Quincas Borba. Machado de Assis esteve atento à configuração da crise psíquica de Rubião, conforme atestam as mudanças de uma versão a outra.

Na reescrita de Quincas Borba, conforme vimos por meio de alusões aos estudos de Meyer, Kinnear, Gledson e Suriani, Machado realizou uma série de modificações que permitem diversas interpretações. Em nosso caso, mostraremos que é possível detectar diferenças entre as versões que apontam para a busca de uma exposição mais acentuada do discurso psíquico de Rubião no texto em livro. Percebemos cortes e alterações textuais desde o capítulo 1 do romance. ${ }^{4}$

Quadro 1:

\begin{tabular}{|l|l|}
\hline \multicolumn{1}{c|}{ Versão em folhetim de Quincas Borba } & Versão em livro de Quincas Borba \\
& \multicolumn{1}{|c|}{1} \\
$\begin{array}{l}\text { [...] Afinal elevam-se-lhe as reflexões; a } \\
\text { alma pode meditar sobre si mesma. Há } \\
\text { um ano que era ele? Professor. Que é ele } \\
\begin{array}{l}\text { agora? Proprietário. [...] } \\
\text { (ASSIS, on-line) }\end{array}\end{array}$ & $\begin{array}{l}\text { pensava em outra cousa. Cotejava o } \\
\text { passado com o presente. Que era, há um } \\
\text { ano? Professor. Que é agora? Capitalista. } \\
{[\ldots]}\end{array}$ \\
& (ASSIS, 1977, p. 107, grifo meu) \\
\hline
\end{tabular}

Dentre as mudanças operadas no capítulo 1 - antigo capítulo XX -, notamos a supressão do pronome pessoal "ele", o que diminui a distância discursiva entre narrador e personagem. Após a comparação do "passado

\footnotetext{
${ }^{4}$ Nas referências aos capítulos da versão em livro, utilizamos numerais arábicos; já nas da versão em folhetim, numerais romanos.
} 
com o presente", introduzida pelo imperfeito do verbo "cotejar", tempo afim ao uso do discurso indireto livre, seguem questionamentos acerca do passado que, ao mesmo tempo, são do narrador, que nos fornece informações sobre a trajetória do personagem, e de Rubião, que rememora sua antiga condição e enxerga o presente a partir de sua posição de proprietário abastado: "Olha para si, para as chinelas [...], para a casa, para o jardim, para a enseada, para os morros e para o céu; e tudo, desde as chinelas até o céu, tudo entra na mesma sensação de propriedade" (ASSIS, 1977, p. 107). Assim, em diálogo com alterações no restante do capítulo, que enxugam e trazem um novo dinamismo ao texto, a exclusão do pronome "ele" em dois momentos resultou num modo de expressão situado na fronteira do discurso narrativo e do discurso interior. ${ }^{5}$

Nesse sentido, o deslocamento do capítulo XX para o começo do livro é uma mudança estrutural que coloca Rubião em destaque na abertura de Quincas Borba. Mas ela não atua isoladamente no processo de reescrita do início da obra, articulando-se com exclusões de palavras, como no caso do pronome "ele", que intensificam a representação da interioridade do protagonista. Mais adiante, no capítulo 9, além das exclusões de palavras, há inclusões que expandem a representação do discurso interior de Rubião no texto.

O capítulo 9 provém da fusão dos capítulos VII e VIII da versão em folhetim. Nesse ponto da narrativa, o filósofo Quincas Borba está a caminho do Rio de Janeiro, e Rubião acata o pedido do amigo para que cuidasse do seu cachorro em Barbacena. O ex-professor pensa então na opinião pública, que poderia responsabilizá-lo por permitir que o amigo ensandecido e com a saúde frágil fizesse uma viagem longa sozinho. Mais à frente, lemos que algumas pessoas mofavam de Rubião por sua condição de cuidador de cão, algo que o atormenta. Contudo, o mineiro procura confortar a si mesmo com a ideia de uma recompensa futura, que seria um possível legado deixado pelo amigo. Assim, o narrador nos faz perceber o mundo narrado a partir do ponto de vista de Rubião, conforme podemos ler nos quadros 2 e 3.

Quadro 2:

\begin{tabular}{|c|c|}
\hline Versão em folhetim de Quincas Borba & Versão em livro de Quincas Borba \\
VII & 9 \\
\hline
\end{tabular}

${ }^{5}$ Para aprofundamento teórico sobre as perguntas retóricas, exclamações retóricas, discurso narrativo e discurso interior, ver Bakhtin (2006, p. 177). 
Em casa, passadas muitas horas, é que lhe acudiu uma ideia terrífica. Podiam crer que ele próprio incitara o outro à viagem, para o fim de o matar mais depressa, e entrar na posse do legado, se é que realmente estava incluso no testamento. Rubião ficou aturdido um dia inteiro; tinha vergonha e remorsos. Via na imaginação o cadáver do Quincas Borba, pálido, horrendo, fitando nele um olhar de ameaça, ou, mais exatamente, abrindo-lhe dous óculos para a eternidade, pelos quais via o julgamento e o castigo. Rubião era temente a Deus, e a ação pareceu-lhe tão imoral que ele resolveu, se acaso o fatal desfecho se desse em viagem, abrir mão do que o outro lhe tivesse deixado em testamento. Só assim pôde passar tranquilo a segunda noite.

(ASSIS, on-line)
Horas depois, teve Rubião um pensamento horrível. Podiam crer que ele próprio incitara o amigo à viagem, para o fim de o matar mais depressa, e entrar na posse do legado, se é que realmente estava incluso no testamento. Sentiu remorsos. Porque não empregou todas as forças, para contê-lo? Viu o cadáver do Quincas Borba, pálido, hediondo, fitando nele um olhar vingativo; resolveu, se acaso o fatal desfecho se desse em viagem, abrir mão do legado.

(ASSIS, 1977, p. 117, grifo meu)

Quadro 3:

\begin{tabular}{|c|c|}
\hline Versão em folhetim de Quincas Borba & Versão em livro de Quincas Borba \\
\hline VIII & 9 \\
\hline $\begin{array}{l}\text { Não foi só o médico, os conhecidos da } \\
\text { cidade começaram a mofar dele e da } \\
\text { singular incumbência de guardar um } \\
\text { cão, em vez de ser o cão que o guardasse } \\
\text { a ele. Vinha a risota, choviam as } \\
\text { alcunhas. Em que havia de dar o } \\
\text { professor! sentinela de cachorro! Rubião } \\
\text { tinha medo da opinião, e chegou a achar } \\
\text { que, em verdade, era ridículo; fugia aos } \\
\text { olhos estranhos, o mais que lhe era } \\
\text { possível; em casa, chegava a olhar com } \\
\text { fastio para o cachorro; dava-se ao diabo, } \\
\text { arrenegava da vida... } \\
\text { (ASSIS, on-line) }\end{array}$ & $\begin{array}{l}\text { Algumas pessoas começaram a mofar do } \\
\text { Rubião e da singular incumbência de } \\
\text { guardar um cão em vez de ser o cão que } \\
\text { o guardasse a ele. Vinha a risota, } \\
\text { choviam as alcunhas. Em que havia de } \\
\text { dar o professor! sentinela de cachorro! } \\
\text { Rubião tinha medo da opinião pública. } \\
\text { Com efeito, parecia-lhe ridículo; fugia } \\
\text { aos olhos estranhos, olhava com fastio } \\
\text { para o animal, dava-se ao diabo, } \\
\text { arrenegava da vida. Não tivesse a } \\
\text { esperança de um legado, pequeno que } \\
\text { fosse... Era impossível que lhe não } \\
\text { deixasse uma lembrança. } \\
\text { (ASSIS, 1977, p. 118, grifo meu) }\end{array}$ \\
\hline
\end{tabular}


O rearranjo que resultou no capítulo 9 da versão em livro proporciona outra experiência de leitura não apenas pela exclusão de palavras, frases ou até mesmo parágrafos da antiga versão, mas também por alguns acréscimos. No fragmento que remete à versão em folhetim presente no quadro 2 , o fato de Rubião ser "temente a Deus" opera como elemento decisivo para que ele abrisse mão do legado. Essa informação, juntamente com o restante da parte final do parágrafo, não reaparece na versão em livro. Nela, mais que um problema advindo da relação homem/Deus e explicado pelo narrador, o discurso narrativo mostra a interioridade do personagem vivenciando a problemática presente de forma mais matizada. A pergunta sobre o porquê de não ter empregado todas as forças para contê-lo, existente apenas no livro, novamente exprime um discurso situado na fronteira entre o discurso narrativo e o discurso - que habita a interioridade - de Rubião. Vale lembrar que, no folhetim, o romance conta mais de 26.500 palavras e possui, na versão em livro, mais ou menos 11.500 (GLEDSON; SILVA, on-line), ou seja, as inserções são algo pouco usual e merecem consideração. Desse modo, mais enxuto e com uma ligeira mas significativa inclusão, o parágrafo apresenta um discurso que ruma mais para a heterogeneidade, baralhando as vozes do narrador e personagem.

Já no quadro 3, há mudanças sutis em todo o parágrafo. Nele, chama a atenção a inclusão de um outro trecho. $O$ fragmento acrescentado reforça $o$ interesse material de Rubião, mostrando que, apesar de ingênuo, ele também agia motivado pela "esperança de um legado, pequeno que fosse...", zona discursiva em que o discurso indireto livre não possibilita atribuir a responsabilidade do enunciado apenas ao narrador. Na frase seguinte - "Era impossível que lhe não deixasse uma lembrança" - a representação da interioridade de Rubião infiltra-se mais fortemente na narração, evidenciando a parcela de interesse do personagem na herança de Quincas Borba.

Na sequência do romance, de maneira semelhante ao que ocorreu na reescrita do capítulo 9, os capítulos IX e X da versão em folhetim tiveram a extensão do texto reduzida e deram origem ao capítulo 10 da versão em livro. Contudo, em meio ao trabalho de redução textual, o escritor incluiu, entre o final do capítulo IX e o começo do capítulo $X$ da versão em folhetim, uma passagem na qual se explora a repercussão que a leitura da carta enviada por Quincas - aquela em que o filósofo afirma ser Santo Agostinho - causa em Rubião. Esses capítulos foram publicados em datas diferentes: o capítulo IX saiu em 15 de julho de 1886, e o capítulo X, em 31 de julho de 1886. Sem as 
questões práticas e materiais envolvendo a serialização da narrativa, na versão em livro Machado delimita a cena a um único capítulo, diminui os diálogos e, em mais um caso pouco comum de inclusão na reescrita do romance, procura expandir a influência do ponto de vista de Rubião na narrativa, como podemos observar no quadro 4:

Quadro 4:

\begin{tabular}{|c|c|}
\hline Versão em folhetim de Quincas Borba & Versão em livro de Quincas Borba \\
\hline IX & 10 \\
\hline $\begin{array}{c}\text { "[...] Adeus, até breve, vou daqui a dias, } \\
\text { amanhã, etc. - Joaquim Borba dos } \\
\text { Santos." }\end{array}$ & $\begin{array}{l}{[. . .] \text { adeus, adeus... Teu do coração }} \\
\qquad \text { "Quincas Borba". }\end{array}$ \\
\hline $\begin{array}{l}\text { Rubião leu e releu a carta; não havia } \\
\text { dúvida, Quincas Borba estava } \\
\text { completamente doudo. Nisto muitas } \\
\text { ideias entraram-lhe no cérebro; ele } \\
\text { atordoado, ficou alhar para o chão. } \\
\qquad \mathrm{X} \\
\text { Nesse mesmo instante, entrou-lhe o } \\
\text { médico em casa. [...] } \\
\text { (ASSIS, on-line - O primeiro grifo é do } \\
\text { autor; o segundo, meu) }\end{array}$ & $\begin{array}{l}\text { Rubião mal sustinha o papel nos dedos. } \\
\text { Passados alguns segundos, advertiu que } \\
\text { podia ser um gracejo do amigo, e releu a } \\
\text { carta; mas a segunda leitura confirmou a } \\
\text { primeira impressão. Não havia dúvida; } \\
\text { estava doudo. Pobre Quincas Borba! } \\
\text { Assim, as esquisitices, a frequente } \\
\text { alteração de humor, os impetos sem } \\
\text { motivo, as ternuras sem proporção, não } \\
\text { eram mais que prenúncios da ruína total } \\
\text { do cérebro. Morria antes de morrer. Tão } \\
\text { bom! Tão alegre! Tinha impertinências, é } \\
\text { verdade; mas a doença explicava-as. } \\
\text { Rubião enxugou os olhos, úmidos de } \\
\text { comoção. Depois, veio a lembrança do } \\
\text { possível legado, e ainda mais o afligiu } \\
\text { por lhe mostrar que bom amigo ia } \\
\text { perder. } \\
\text { Quis ainda uma vez ler a carta, agora } \\
\text { devagar, analisando as palavras, } \\
\text { desconjuntando-as, para ver bem o } \\
\text { sentido e descobrir se realmente era uma } \\
\text { troça de filósofo. Aquele modo de o } \\
\text { descompor brincando, era conhecido; mas } \\
\text { o resto confirmava a suspeita do desastre. } \\
\text { Já quase no fim, parou enfiado. Dar-se-ia } \\
\text { que, provada a alienação mental do }\end{array}$ \\
\hline
\end{tabular}




\begin{tabular}{|l|l|}
\hline & testador, nulo ficaria o testamento, e \\
perdidas as deixas? Rubião teve uma \\
vertigem. Estava ainda com a carta \\
aberta nas mãos, quando viu aparecer o \\
doutor [...]. \\
(ASSIS, 1977, p. 119, grifos meus)
\end{tabular}

Na versão em folhetim, o impacto da carta na interioridade de Rubião não vai além da constatação de que Quincas Borba estava doido. Embora contenha fragmento discursivamente heterogêneo, a passagem é mais resumida e simples que a presente na versão em livro. Nesta, ao contrário, acrescenta-se ao trecho o movimento psíquico de Rubião pela via do discurso indireto livre para fundamentar a hipótese de que seu amigo ensandecera. Emocionado, com os olhos úmidos, a aflição aumenta logo após o personagem ter se lembrado do possível legado, numa revelação maliciosa do narrador, posto que a aflição de Rubião aumentaria na medida em que a possível herança vem à memória. No final do enunciado, a qualificação "bom amigo" poderia estar entre aspas, como se proveniente do protagonista, revelando uma abordagem irônica de sua compaixão. Num segundo momento, em que Rubião lê mais pausadamente a carta, o discurso indireto livre colabora para mostrar que ele passa a ter certeza da insanidade do amigo e, constrangido, a temer a nulidade do testamento. Acompanhamos, em breve passagem do romance, um movimento interior que vai da comoção com a condição precária de Quincas Borba até o cálculo de quanto Rubião poderia lucrar com a morte do amigo. Em comparação com o folhetim, na versão em livro a heterodiscursividade é intensificada pelo discurso indireto livre e rende um tratamento mais eficaz à mistura de elementos contrastantes - o desvelo com o amigo e o interesse pela herança - que habitam o ser fictício.

Portanto, em Quincas Borba, o devassamento da interioridade de Rubião culmina na abertura de sentido operada pela presença recorrente do discurso indireto livre. Procedimento fundamental no romance moderno, ao contrário de "realçar a superioridade do narrador sobre o personagem", o indireto livre tende à "igualdade (entre narrador e personagem)": "no primeiro caso, prevalece uma concepção didática", já "no segundo caso, a mensagem torna-se implícita e por vezes quase inadvertida" (MORETTI, 2003, p. 27). De acordo com Franco Moretti, o discurso indireto livre mescla elementos linguísticos próprios do discurso direto (personagem) e do 
discurso indireto (narrador), geralmente ocorrendo próximos das reviravoltas da narrativa:

Nesses momentos críticos há por assim dizer um excedente de intensidade que permite "saltar" da história ao discurso, vencendo a distância - que estruturalmente é enorme - entre a voz da personagem e a do narrador. Mas esses momentos são também ideais para o exato oposto do indireto livre, ou seja, para extrair a moral dos acontecimentos mediante digressões sobre as desastrosas consequências de uma conduta errada. Ao se acercar desses desdobramentos, então, quem escreve se depara com uma bifurcação: pode realçar a superioridade do narrador sobre a personagem com um trecho didático ou exprimir a sua tendência à igualdade por meio do indireto livre. Uma coisa ou outra. E o que está em jogo aqui não é apenas uma questão de estilo: são dois modos opostos de entender literatura. No primeiro caso prevalece uma concepção didática, segundo a qual um romance é acima de tudo um meio para transmitir uma mensagem ética unívoca e explícita (e de regra muita severa). No segundo caso, a mensagem torna-se implícita e por vezes quase inadvertida. (MORETTI, 2003, p. 27)

Assim, o discurso indireto livre colabora para a indeterminação de sentido da narrativa, afastando-a do didatismo. Sem pretender evidenciar quem exatamente "fala" no discurso indireto livre, cumpre observar que estamos lidando com um procedimento fundamental para a leitura do romance moderno, que pode remeter a ideias conflitantes acerca dele, ora visto como um "tipo de ruptura política que põe o romance europeu em conflito com a cultura dominante", ora como uma forma de "controle social", ou, ainda, como a "voz do contrato social" (MORETTI, 2003, p. 32). No caso de Quincas Borba, qual o sentido que o discurso indireto livre assume?

Na reescrita de Quincas Borba, o trabalho de manutenção e expansão de passagens em que ocorre o baralhamento discursivo entre narrador e protagonista pode ser verificado, além dos capítulos 1, 9 e 10, nos capítulos 12, 18, 62, 90 e 97 da versão em livro. Entretanto, na parte final do romance, essas alterações escasseiam quando da articulação entre o narrador e Rubião. A hipótese mais evidente seria a de que Machado resolvera seus problemas criativos depois das grandes pausas de 1888 e 1889 e dera prosseguimento a uma escrita que seria plenamente reaproveitada na versão em livro. Contudo, se atentarmos para o desenvolvimento do plano interno da narrativa, perceberemos que não raro o narrador executa um movimento de afastamento da psique de Rubião em direção à interioridade de outros 
personagens. Isso fica mais perceptível quando a crise psíquica do protagonista se intensifica, e o narrador acompanha o personagem numa postura mais distanciada em relação à sua interioridade. Os trânsitos psíquicos de outros personagens, por outro lado, passam a ser mais explorados. Esse movimento pode ser observado na reescrita da obra: nos capítulos 105, 139, 159 e 169, em que temos passagens nas quais as interioridades de Maria Benedita e Sofia são desvendadas para o leitor, Machado retrabalhou o texto de modo semelhante ao que fizera nos capítulos da primeira metade envolvendo Rubião, reduzindo trechos, fazendo modificações pontuais, mas mantendo passagens em que há discurso indireto livre.

Acerca do movimento de aproximação e distanciamento do narrador em relação a Rubião, não por acaso, no capítulo 99, em momento no qual a condição psíquica do personagem começa a rumar com mais celeridade ao abismo, ocorre uma fratura entre o seu discurso e o do narrador. Após certo tempo da chegada ao Rio de Janeiro, Rubião não alcança o amor de Sofia, e a vida na Corte transforma-se em tédio. Entregue aos próprios pensamentos, o rico herdeiro lê o mundo de modo exagerado e desequilibrado: ao ter encontrado uma carta com a letra de Sofia endereçada a Carlos Maria, é dominado pelo ciúme, e a imaginação se encarrega de perverter o conteúdo da carta. Com o texto mais resumido e denso em relação às passagens provenientes da versão em folhetim, o capítulo focaliza a tensão psicológica de Rubião, que sem ler a carta recrimina seu conteúdo, atribuindo a ela uma linguagem maligna e vil, escrita por uma adúltera. A visão negativa e moralista diante do possível adultério de Sofia soa contraditória, pois advém de quem deseja ser amante da esposa do amigo. Eis que em meio ao dilema moral do personagem, indeciso se abria ou não a carta, uma voz surge na narração:

Quadro 5:

\begin{tabular}{|c|c|}
\hline Versão em folhetim de Quincas Borba & Versão em livro de Quincas Borba \\
\hline CXV (i) & 99 \\
\hline $\begin{array}{l}\text { Deve ser assim, quando um homem } \\
\text { medita algum crime. Rubião, em casa, } \\
\text { tirou a carta e mirou-a outra vez; as } \\
\text { mãos tremiam-lhe, reproduzindo o } \\
\text { estado da consciência. Se abrisse a carta, } \\
\text { saberia tudo, tudo, tudo; ficava apto para }\end{array}$ & $\begin{array}{l}\text { Em casa, tirou-a e mirou-a outra vez; as } \\
\text { mãos hesitavam reproduzindo o estado } \\
\text { da consciência. Se abrisse a carta, saberia } \\
\text { tudo. Lida e queimada, ninguém mais } \\
\text { conheceria o texto, ao passo que ele teria } \\
\text { acabado por uma vez com essa terrível }\end{array}$ \\
\hline
\end{tabular}


recompor-se. Lida e queimada, ninguém mais conheceria o texto, ao passo que ele teria rompido por uma vez com essa terrível fascinação que o fazia penar ao pé daquele abismo de opróbrios... Não sou eu que o digo, é ele; ele é que junta todos esses nomes ruins, ele é que para no meio da sala, com os olhos no tapete, em cuja trama figura um turco indolente, com o chibuque nos lábios, olhando para o Bósforo... Devia ser o Bósforo.

(ASSIS, on-line, grifo meu) fascinação que o fazia penar ao pé daquele abismo de opróbrios... Não sou eu que o digo, é ele; ele é que junta esse e outros nomes ruins, ele o que para no meio da sala, com os olhos no tapete, em cuja trama figura um turco indolente, cachimbo na boca, olhando para o Bósforo... Devia ser o Bósforo. (ASSIS, 1977, p. 226-227, grifo meu)

Embora saibamos que o discurso indireto livre não implique necessariamente na compatibilidade de visões de mundo entre narrador e personagem - decorrendo desse fenômeno a ironia, por exemplo -, chama a atenção que a voz narrativa irrompa em primeira pessoa para rejeitar o discurso e atribuí-lo exclusivamente a Rubião. Reforça-se e escancara-se, assim, o desajuste entre narrador e personagem, evidenciando a problemática articulação entre ambos. Nesse caso, temos uma radicalização do movimento de aproximação e distanciamento em Quincas Borba, uma vez que o narrador explora os movimentos da interioridade de Rubião, desvelando suas motivações, contradições e fraquezas, para em seguida rejeitar categoricamente aquilo que seria o discurso interior do personagem, distanciando-se dele.

Nesse sentido, a marginalização social que Rubião sofre em razão de seu desvario repercute em sua marginalização na própria narração, pois, a certa altura, passa a ser rejeitado pelos personagens e pelo próprio narrador. Este, na medida em que acompanha os passos do protagonista rumo ao abismo, aproxima-se das interioridades de outros seres fictícios como forma de mostrar as contradições e iniquidades do mundo. Os pontos de vista de Sofia, d. Fernanda, dr. Falcão e a mãe de Deolindo, menino que Rubião salvara de atropelamento, assinalam o repúdio ou estranhamento, na sociedade fluminense que se modernizava, a condutas não normalizadas, como a de Rubião.

Portanto, a interferência da interioridade de Rubião na narração é um dos aspectos decisivos no processo de reescrita de Quincas Borba. Embora desde a versão em folhetim a crise psíquica do personagem receba tratamento significativo no plano estilístico do romance, Machado de Assis reelaborou o texto nesse sentido, efetuando alterações na versão em livro de 
modo a intensificar as construções nas quais o discurso tende ao heterogêneo, incluindo a presença mais intensa do discurso indireto livre.

No momento em que a crise psíquica de Rubião se agrava, o narrador intensifica sua busca de outros universos psíquicos, mostrando divagações e cálculos internos de vencidos e vencedores. Da articulação entre tais passagens e delas com o plano de ação do romance, o leitor poderia lembrar que não raro o ponto de vista determina a apreciação dos fatos, algo observado pelo narrador no capítulo 18: "Tão certo é que a paisagem depende do ponto de vista, e que o melhor modo de apreciar o chicote é ter-lhe o cabo na mão" (ASSIS, 1977, 126-127).

Nesse sentido, as formas de transmissão do discurso de outrem atuam em articulação com a relativização do mundo narrado em Quincas Borba: a dinâmica discursiva de aproximação e distanciamento do narrador em relação ao ponto de vista dos personagens, em que o discurso indireto livre opera como procedimento fundamental, sugere um modo de relação entre os seres ficcionais baseado no uso e no descarte do outro. Assim, o tratamento do narrador dado ao protagonista e demais personagens, sempre recuperando a distância necessária para um olhar irônico acerca da representação de suas interioridades, insinua, no próprio modo de narrar, a moderna coisificação dos homens por outros homens.

\section{Referências}

ASSIS, Machado de. Quincas Borba. 2. ed. Rio de Janeiro: Civilização Brasileira; Brasília: INL, 1977. 346 p.

Quincas Borba - A Estação. Disponível em: <http:// www.machadodeassis.net/hiperTx_romances/obras/quincasborbaaestacao.h tm>. Acesso em: 1 mar. 2014.

BAKHTIN, Mikhail. Marxismo e filosofia da linguagem: problemas fundamentais do método sociológico da linguagem. São Paulo: Hucitec, 2006. 203 p.

. Teoria do romance I: a estilística. Tradução, comentários, glossário e notas de Paulo Bezerra. São Paulo: Editora 34, 2015. 256 p.

GLEDSON, John. Quincas Borba. In: Machado de Assis: ficção e história. Trad. Sônia Coutinho. 2. ed. rev. São Paulo: Paz e Terra, 2003. p. 73-134. ; SILVA, Ana Cláudia Suriani da. Guia para melhor entender o texto da versão-folhetim de Quincas Borba. In: ASSIS, Machado de. Quincas Borba - A Estação. Disponível em: <http://www.machadodeassis.net/hiperTx romances/obras/quincasborbaaestacao.htm>. Acesso em: 1 mar. 2014. 
KINNEAR, John C. Machado de Assis: to believe or not to believe? The Modern Language Review, v. 71, n. 1, p. 54-65, jan. 1976. Disponível em: $<$ http://www.jstor.org/stable/3724380>. Acesso em: 9 abr. 2015.

MEYER, Augusto. Quincas Borba em variantes. In: A chave e a máscara. Rio de Janeiro: Edições O Cruzeiro, 1964. p. 173-189.

MORETTI, Franco. O século sério. Trad. Alípio Correa e Sandra Correa. Novos Estudos CEBRAP, n. 65, p. 3-33, mar. 2003.

SEMINATTI, Tiago. A interioridade em abismo: estudo sobre o discurso indireto livre e a crise da forma em Quincas Borba. 2016. 124 p. Dissertação (Mestrado em Literatura Brasileira) - Faculdade de Filosofia, Letras e Ciências Humanas, Universidade de São Paulo, São Paulo, 2016.

SILVA, Ana Cláudia Suriani da. Machado de Assis's "Philosopher or dog?": from Serial to Book Form. Oxford: Legenda, 2010. 200 p. Machado de Assis: do folhetim ao livro. São Paulo: NVersos, 2015. 288 p.

TIAGO SEMINATTI é doutorando em Literatura Brasileira na Faculdade de Filosofia, Letras e Ciências Humanas (USP) com o projeto "Radicalidade e contenção no Memorial de Aires, o derradeiro romance de Machado de Assis". Realizou mestrado em Literatura Brasileira na Faculdade de Filosofia, Letras e Ciências Humanas (USP) entre 2014 e 2016, com a dissertação "A interioridade em abismo: estudo sobre o discurso indireto livre e a crise da forma em Quincas Borba". Graduado e licenciado em Letras pela Faculdade de Filosofia, Letras e Ciências Humanas (USP). (iD http://orcid.org/00000001-6493-1419. E-mail: tiago.seminatti@gmail.com

Recebido: 25.01.2019

Aprovado: 20.05.2019 